Research article

\title{
Plants struggling to receive proper identity at Bhadaure Tamagi of Kaski district, Nepal
}

\author{
Bimal Bahadur Kunwar* \\ Research, Community Development and Conservation Center (C3DR), Pokhara-25, Hemja, Nepal \\ *Corresponding Author: bimalnature@gmail.com \\ [Accepted: 19 July 2017]
}

\begin{abstract}
Neglected and underutilized plant species have a potential to contribute to food security and poverty alleviation. Most plant species consumed as food across the world are neglected and underutilized. These includes plants with edible fruits, grains, leaves, nuts, oils, roots and tubers, fibers, medicines, spices, stimulants and their derived products. Until now, there was very limited information available on the utility of plants for different purposes in the study area. Thus, to minimize the gaps, the research was carried out at Bhadaure village of Kaski District, Nepal. Data were collected from the different sites through the application of Participatory Research Appraisal methods i.e. direct observation, household survey, individual interviews and key informant interview. This was followed by the field visit with the help of community members where collection of the plant samples and capturing of the photograph was done. Then each species was evaluated for nine parameters (extent of the production, extent of consumption, degree of consumption, perceived nutritional value, cultural importance, medicinal properties, market use, market value and contribution to household income). From the community interaction and field visit a list of 66 plants were extracted as underutilized plants in the study area. They were from various habitats. About $55 \%$ of the species were collected from natural or semi-natural vegetation, particularly forest. $33 \%$ of the plants were used for vegetable. The collection or harvesting period of the recorded plant were varies on the case of species. The availability of wild plants has also declined drastically. Young generation was not so much interested in these plants. Some of these plants were observed on market places being sold at competitive prices. Specific household members consume these plants. Commercialization of these fruits is mainly undertaken by the low resource base farmers.
\end{abstract}

Keywords: Food security - Neglected and underutilized plant - Participatory research appraisal Farmer.

[Cite as: Kunwar BB (2017) Plants struggling to receive proper identity at Bhadaure Tamagi of Kaski district, Nepal. Tropical Plant Research 4(2): 286-296]

\section{INTRODUCTION}

There are 350,000 plant species recorded in the world, out of them 80,000 species are edible for humans. The cultivated plant species are represented from 55 families (Fuleky 2009). For both the poorest and the riches socio-economic groups of the people have received important sources of protein, fats, vitamins, and minerals from many thousands of wild plant species (Akhtar 2001, ICIMOD 2010, Aryal 2010). In many parts of the world, the use of wild plants as a vegetable and fruits is very common (Bussmann et al. 2006, Cavender 2006, Pieroni et al. 2007, Dutta et al. 2016). Most plant species that are used for food across the globe are neglected and underutilized. Search for the alternative plants that are edible for humans as food or fruits havebeen done through the process of trials and errors by various tribes, in turn domesticating the useful plants (Prescott \& Prescott 1990, Scherrer et al. 2005, Bajpai et al. 2016, Dutta et al. 2016). Current estimation of more than 7,000 plant species are cultivated or harvested from the wild for food in global scale.

In Nepal, estimation of plants between 6,500 species of flowering plants (WCMC 1994) and 5,800 (Hara et al. 1978, 1979, 1982) have been done, out of which 1,500 are considered beneficial (Manandhar 2002). Out of these, 651 species are economically useful including 440 species of wild food plants and about 200 plant species 
are consumed as vegetables (Manandhar 1982), most of them, however, are regarded underutilized or neglected. The history of the utilization of the plant resources in Nepal dates back to the work of Banerji (1955). After his work, some workers continued the ethnobotanical study in the 60's and 70's (Pandey 1964, Dobremez 1976). Neglected and Underutilized plant species (NUS) are those species that have a potential to contribute to food security and poverty alleviation and which has not been fully exploited. Increased public awareness about underutilized species was prompted by the Convention on Biological Diversity and the Global Plan of Action for the Conservation and Sustainable Utilization of Plant Genetic Resources for Food and Agriculture (FAO 1996), The Consultative Group on International Agricultural Research (CGIAR 2004) had initiated to include underutilized species as a majorresearch agenda since 2004.

The plant struggling to receive proper identification but have benefitted to the people or NUS have received negligible attention from research and development, and there is little scientific information about them and they are described as "neglected" (Eyzaguirre et al. 1999). These plant species have value addition aspects to diversify the use and shelf-live. Some are highly important for food security; others may prove to have greater potential for income generation, for environmental services such as soil fertility maintenance, scenic and biological pest control. The production and consumption of neglected and underutilized species prop up higher incomes and in good health nutrition and preserves the cookery and cultural traditions of indigenous communities. In many instances, these species are the only crops that can cope with harsh environments unfit for other crops. The coverage of these plants is wide, including plants that provide edible fruits, grains, leaves, nuts, oils, roots and tubers, fibers, medicines, spices, stimulants and their derived products. Therefore, this demands their promotion which should be done in a sustainable manner. Food security and poverty alleviation in rural communities can be strategically improved by diversifying the existing farming systems. Commercialization of these plants is mainly undertaken by the low resource base farmers. The NUS have been overlooked by scientific research and development workers despite the important role they can play in terms of food provision and food culture of the rural poor and livelihoods of many rural and urban communities but their use in terms of diversification is low and subsequently classified as underutilized.

Lack of attention of NUS by stakeholders has resulted in genetic erosion and ultimately their vanishing, which are further restricting development options for the poor. Many underutilized species are particularly beneficial as food and medicine, especially in marginal areas, where they have been selected to withstand stress conditions and contribute to sustainable production with low-cost inputs. Unfortunately, these species have been neglected by researchers in the past and, consequently, the information available regarding their agronomy, yield improvement potential and quality is insufficient.

Historically, a large number 100,000 plant species have been used regularly for food, fiber, industrial, cultural and medicinal purposes and is recognized as being underutilized. However, as a result of modernization of agricultural practices, many of these plant species have been neglected due to their being held in low prize and some to the level that genetic erosion of their gene pools has become extremely severe. At least 7,000 cultivated plant species are currently in use around the world (FAO 2007). By doing this study, the awareness level of the community people regarding in NUS and its importance had been raised to a certain extent. It is recommended that follow-up interventions need to be carried out through on-farm farmer managed trials and value addition technologies on these plants. Priority should be given to exploration, collection, conservation and promotion of both production and value addition technology of these species in this region. There is a wide range of under-utilized plant species which can be cultivated and/or improved and processed. However, owing to the lack of adequate knowledge and other technologies, full potential has not been exploited yet. Addressing these views will be highly relevant to the development of an improved NUS agricultural portfolio. Despite their importance for subsistence, income generation, and culture, the use of traditional vegetables is declining at an alarming rate in all areas of Nepal, combined with genetic and cultural erosion. This occurs particularly in easily accessible regions, where commercialization of the production is possible. The nutritional value of the wild plant species needs to be analyzed and recognized. In addition, their utilization should be promoted to improve livelihoods in rural and urban Nepal (Joshi et al. 2007).

There was limited information on the status of the NUS in the study area and that limits their promotion along with their product value chain in terms of exploiting production potential, processing, effective and efficient marketing. The purpose of this study was, therefore, to identify the underutilized plants in the studied area, the constraints, and assess the potential, production and utilization of these plants. 


\section{MATERIAL AND METHODOLOGY}

Data were collected during expeditions from different sites through the application of Participatory Research Appraisal tools and techniques such as direct observation, household survey, individual interviews and field visits. The research was carried out at Annapurna Gaupalika ward no. 4 (formerly known Bhadaure Tamagi VDC ward no. 1 and 2). It is in the West of Pokhara city (Headquarter of Western Development region of country Nepal or Province number 4) at about $30 \mathrm{~km}$ and is connecting with rural gravel road with regular access to public transportation and GPS location is Latitude 28 $14^{\prime} 4818^{\prime \prime}-28^{\circ} 14^{\prime} 4827^{\prime \prime}$, Longitude 83 $51^{\circ} 3125^{\prime \prime}-$ 83 $51^{\prime} 3128^{\prime \prime}$ and altitude 1405-1959 masl (Fig. 1). There are ca. 243 households in these two wards (193 in Badaure village and 50 in Talibrang).

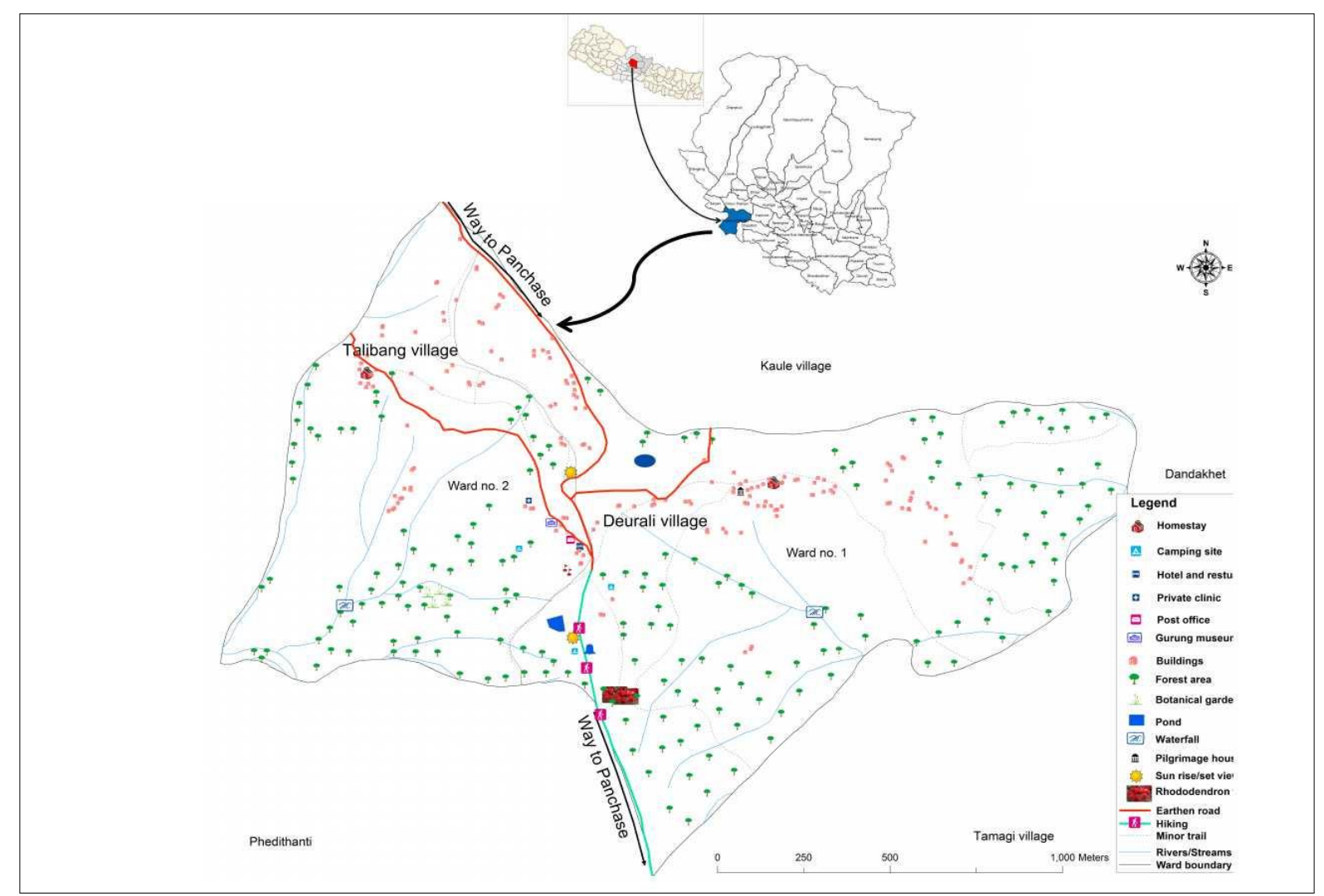

Figure 1. Map of the research area: Bhadaure Tamagi Village.

Fifteen randomly selected individuals were interviewed using semi-structural questionnaire. In addition, a checklist was prepared using focus group and key informant interviews. Through discussion, some key information was recorded on each of the species identified. These are: local vernacular names, type of plant, part used and period of availability of the part used. Each species was evaluated for nine different parameters (extent of production, the extent of consumption, the degree of consumption, perceived nutritional value, cultural importance, medicinal properties, market use, market value and contribution to household income). Then it was followed by the field visit with the help of community members. Informants (local Farmers) were asked to list the plants they considered as underutilized based on their potential and actual utilization including marketing opportunities. Scientific names were determined using the standard book of Flora namely Flowers of the Himalayas (Polunin \& Stainton 1984), Flowers of the Himalaya (Stainton 1988), Dictionary of Nepalese Plant Names (Shrestha 1998) and with consulting local healer. Surfing the internet for latest findings and the search for the publications housed on the library (across national research and development institutions) were also conducted for better documentation of the NUS recorded.

\section{RESULT AND DISCUSSION}

From the community interaction and field visit, a list of 66 numbers of plants was extracted as underutilized plants in the field survey (Table 1). Plants belonging to herb were 22 plants, shrub 18 plants and trees 14 plants. Climbers (13 plants) were also recorded from the present study. Collections of these plants were made from garden (7 plants), cultivated field (32 plants) and wild habitat (63 plants). Most plants were perennial (43 
plants), followed by annual (20 plants) and biannual (2 plants).

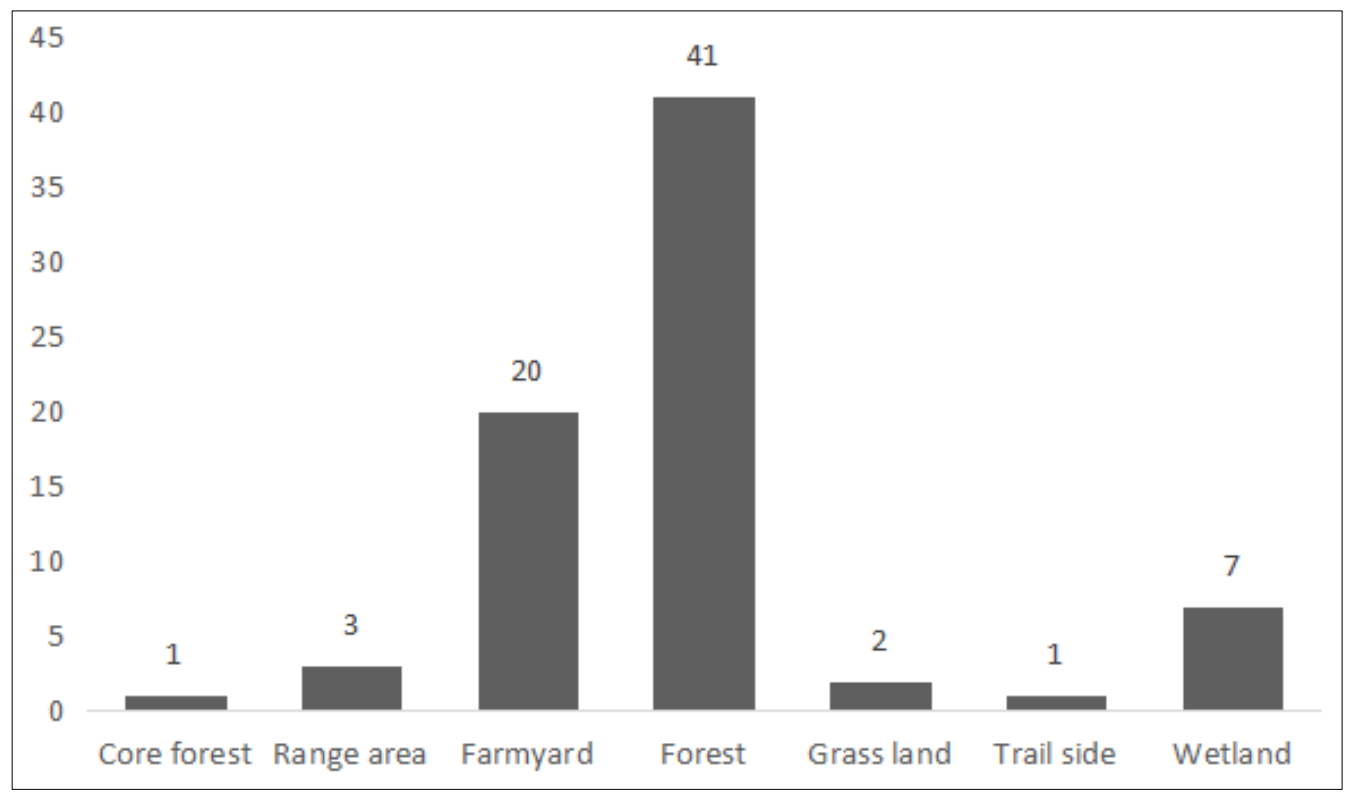

Figure 2. Habitat of the neglected and underutilized plant species.

Special consideration was done about the habitat of the plants, i.e., wetland, farmyard, trail side, core forest, forest, grassland, agricultural land etc. (Fig. 2). About 55\% of the species were collected from natural or seminatural vegetation, particularly forest, whereas nearly out of $27 \%$ for total plants were found from farmyard area. Only 11 plants were found to be cultivated.

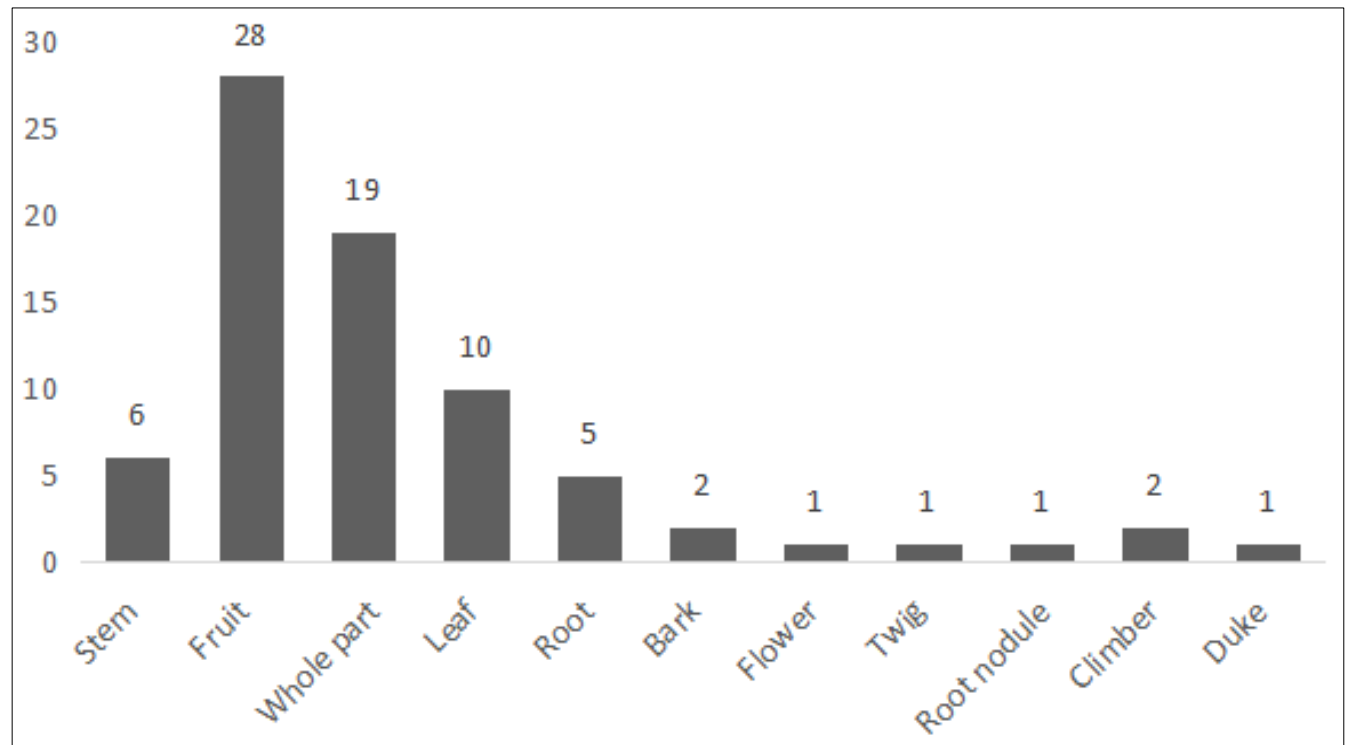

Figure 3. Diversity of plant parts used.

Out of a total of 66 traditional, neglected plants species, 10 species were mainly used for their leaves part, tender shoots or underground stem of 6 plant, flowers of 1 plant, fruits of 28 plant, roots and tubers of 6 plants, whole parts were of 19 plants and so on (Fig. 3). Similarly, 33\% of the plants were used for vegetable, 25 plants for fruit or row food, 10 plants were for a medicinal purpose and so on (Fig. 4). Some plants like Pyrus pashia Buch.-Ham. ex D.Don, Elaeagnus parvifolia Wall. ex Royle, Rhamnaceae Plant, Viburnum mullaha Buch.Ham. ex D. Don, Pyrularia edulis (Wall. ex Floxb.) A. DC., Castanopsis indica (Roxb. ex Lindl.) A.DC., Zanthoxylum armatum DC., Dioscorea deltoidea Wall. ex Griseb., Dioscorea pentaphylla L., Choerospondias axillaris (Roxb.) B.L. Brutt \& A.W. Hill, Artemisia absinthium L. and others were collected for the fruit purposes and they are directly eaten as raw or used for medicinal purposes whereas plants like Polygonum molle D. Don, Pouzolzia zeylanica (L.) Benn., Dendrocalamus hamiltonii Nees \& Am. ex Munro, Colocasia sp. and different types of Niuro and Mushroom are used as vegetable. 


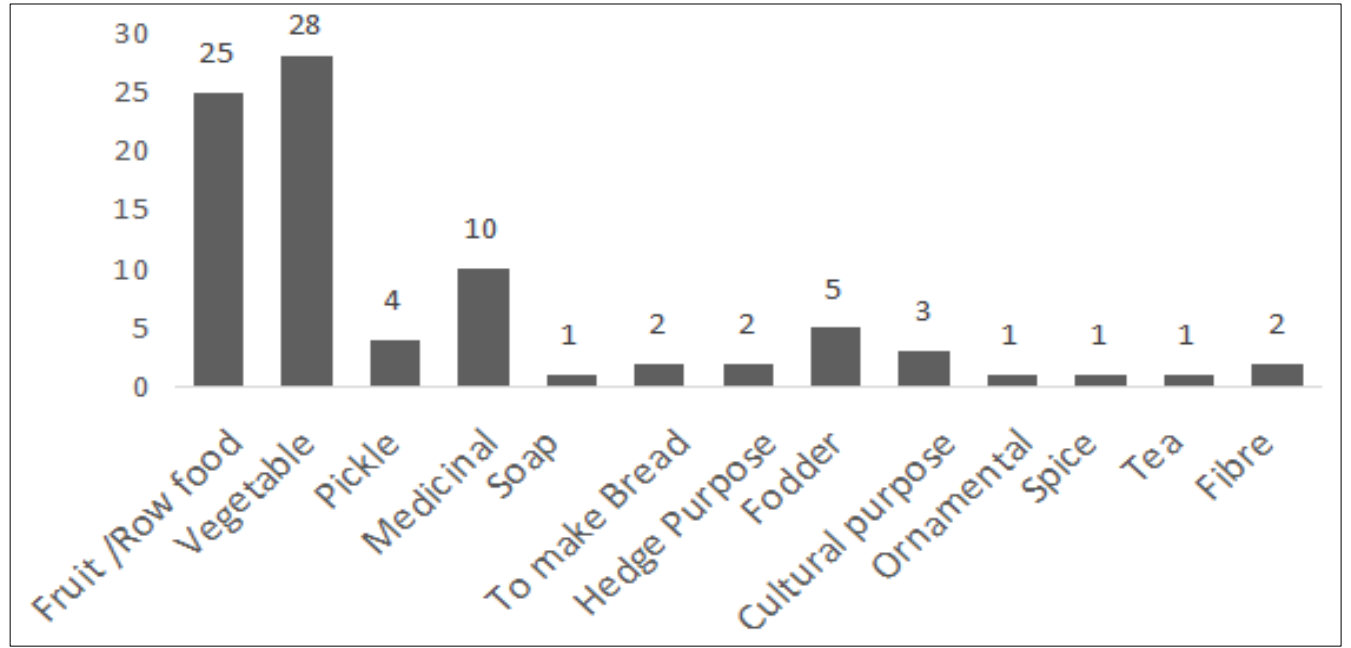

Figure 4. Different uses of the neglected and underutilized plants.

The collection or harvesting period of the recorded plant varied with species. Some of them (20 plants) can be collected every season, while months between June to August i.e. 12\% was found to be the most appropriate period of harvesting (Fig. 5).

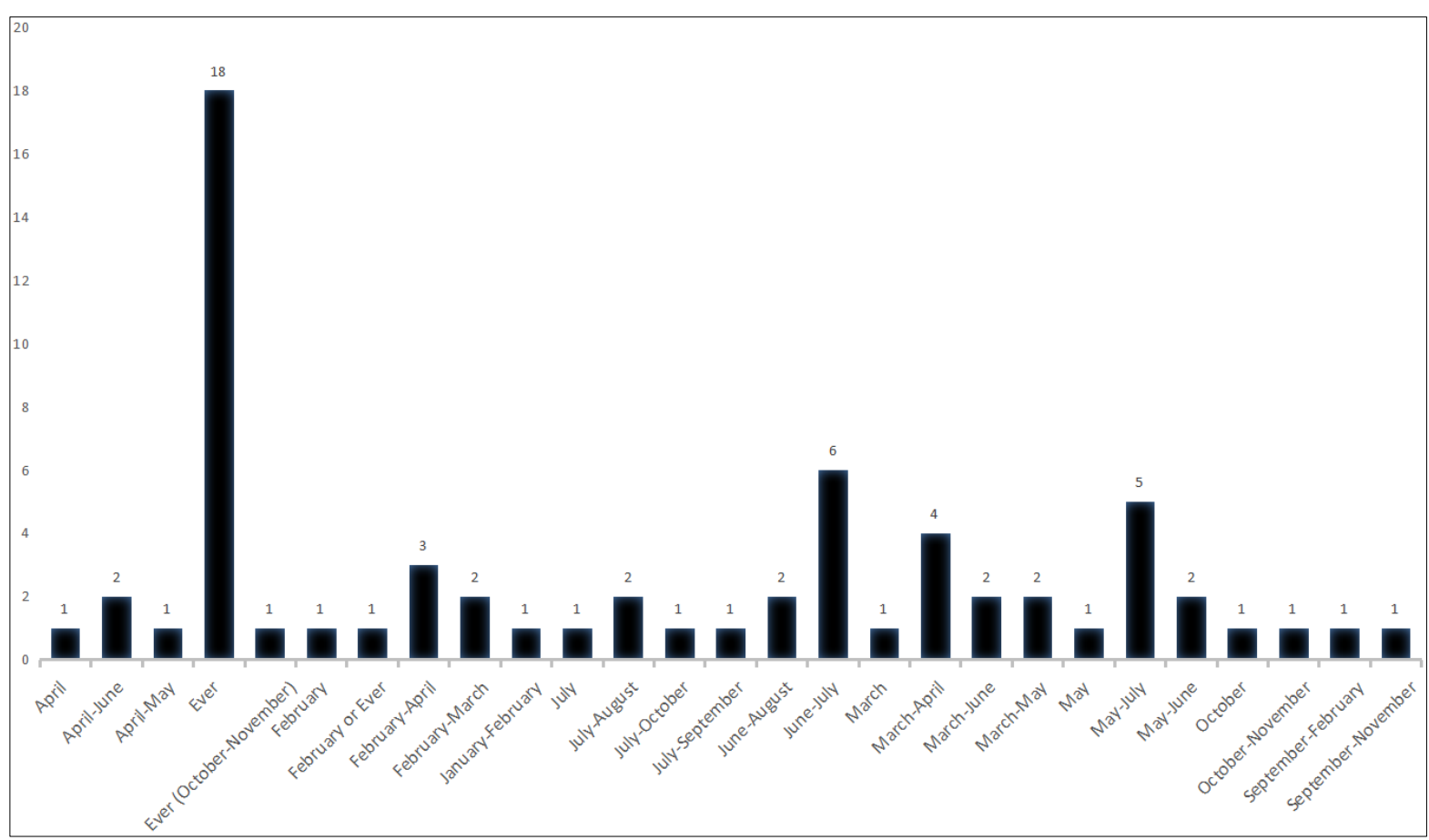

Figure 5. Collecting or harvesting season for neglected and underutilized plants.

According to the respondents, the availability of wild plants has also declined drastically, e.g., because of land-use and habitat change, excessive collection from natural habitats, climate change causing more frequent droughts and fires, and deforestation. In the research area, species such as Dioscorea bulbifera L. and Asparagus racemosus Willd. were endangered because they have a high demand at markets, but are mostly (and often excessively) gathered from their natural habitats. Similarly, plants like Viburnum mullaha, Catunaregam spinosa (Thunb.) Tirveng., Ziziphus sp., Toddalia asiatica (L.) Lam., Dioscorea deltoidea, Citrullus colocynthis (L.) Schrad., Elaeagnus parvifolia, Coccinia grandis (L.) Viogt, Dioscorea pentaphylla, Agaricus campestris L., Oreocnide frutescens (Thunb.) Miq., Cyathea spinulosa Wall. ex Hook., Dioscorea bulbifera, Allium wallichii Kunth, Baman, Pyrularia edulis or many wild species are declining day by day and turning towards rare condition due to their low regeneration power and the lack of proper awareness about the importance of the plants.

Out of the population of the farmers interviewed $40 \%$ were males and $60 \%$ were females. The average age of the respondents was about 38 years with the oldest being 78 years while the youngest being 25 years. The respondent information showed that the collection or harvesting of the plants was done by female mostly and 


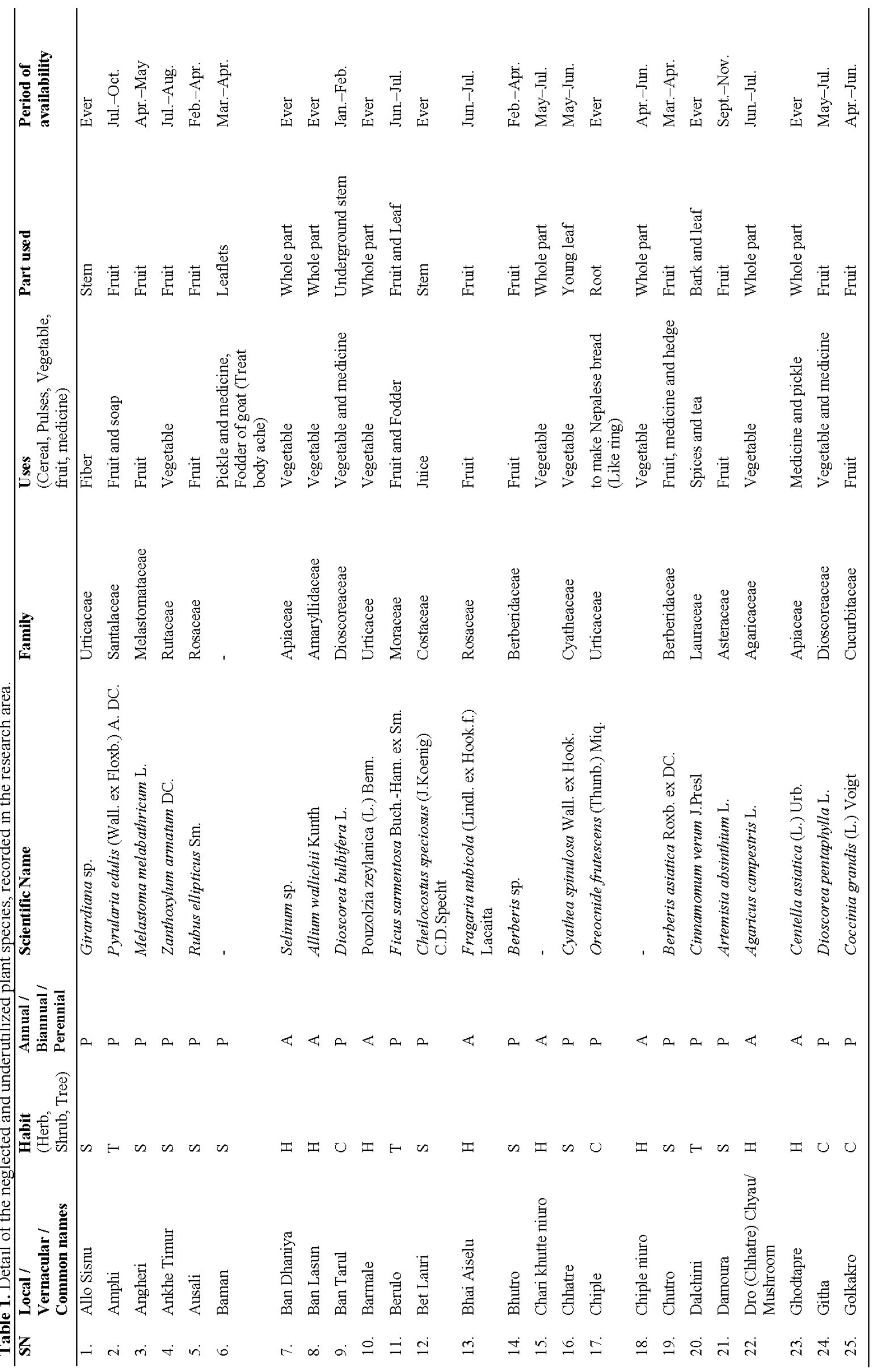

www.tropicalplantresearch.com 


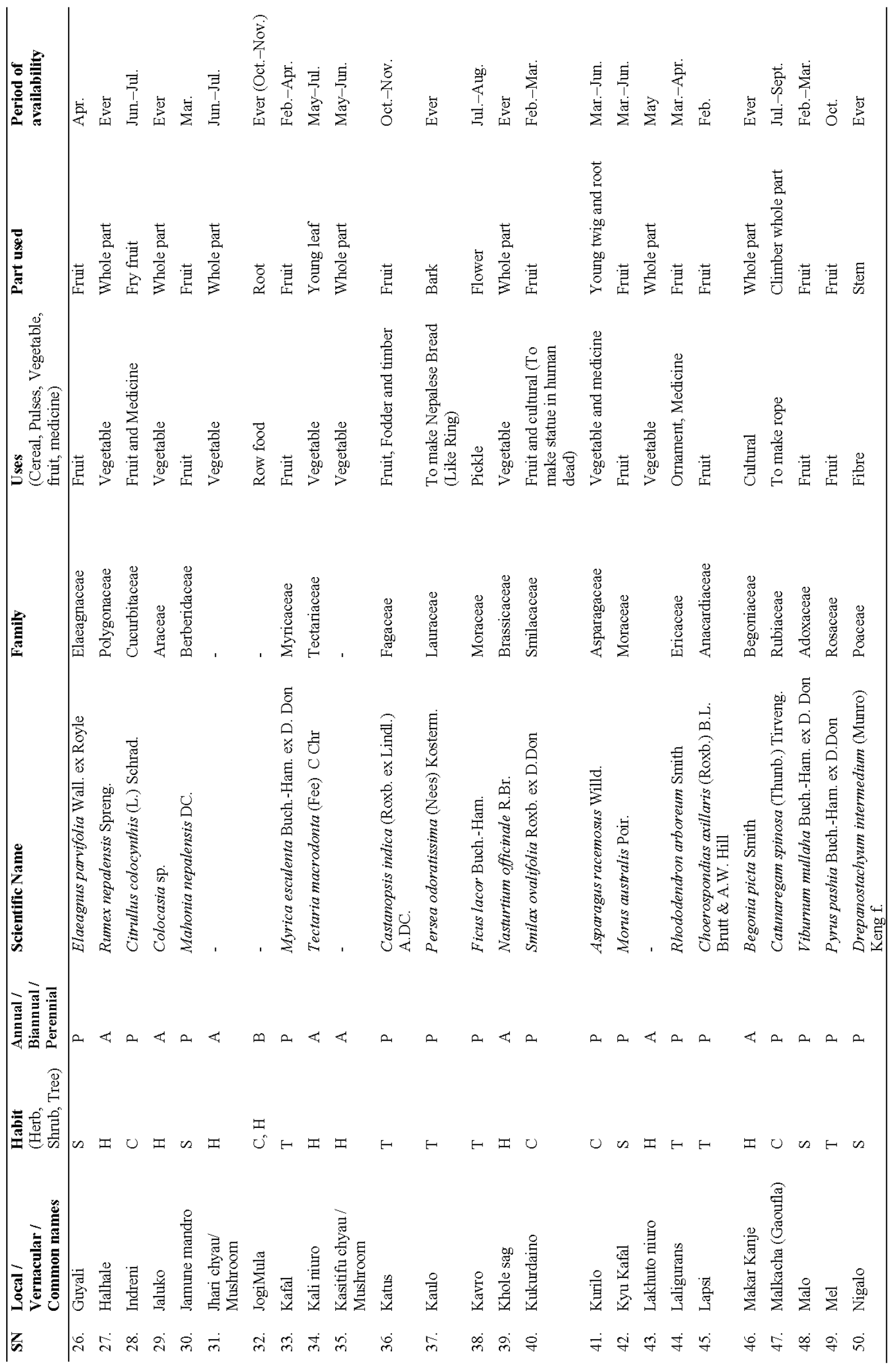

www.tropicalplantresearch.com 


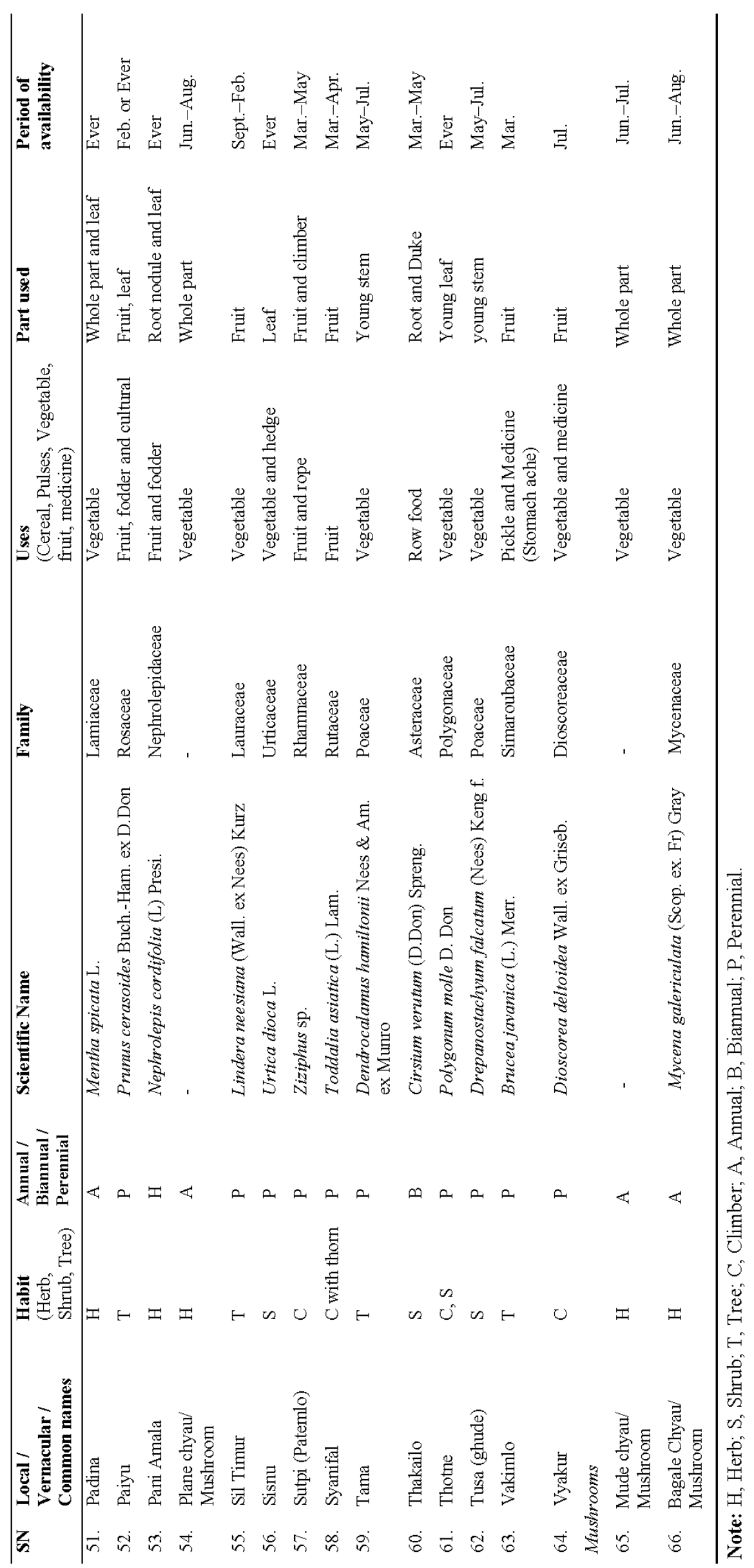

www.tropicalplantresearch.com 
that was especially for their domestic purposes. In one Nepalese site, women above 35 years of age could describe the uses of 65 percent of all edible species, while young men could only describe 23 percent (Shrestha \& Dhillon 2006). Beside this, the male respondent of the study area was comparatively more familiar towards such plant than female. Owing to the advancement of the technology young generation seem not to be interested in utilizing these plants.

Despite their importance for subsistence, income generation, and culture, the use of the plant is declining at an alarming rate in the study area. This occurs particularly in easily accessible regions, where commercialization of the production is easily possible. Only few plants such as Zanthoxylum armatum, Ficus sarmentosa Buch.Ham. ex Sm., Cinnamomum verum J.Presl, Persea odoratissima (Nees) Kosterm., Ficus lacor Buch.-Ham., Asparagus racemosus and Choerospondias axillaris were still cultivated at field-scale in the field surveyed (Table 1) due to their known economic values. Cultivation of exotic plants for subsistence and sale increases more and more at the expense of traditional ones, partly promoted by development programs. These studies mostly did not consider the disadvantages of exotic plants, e.g., the high need of external inputs for successful cultivation or the often rather low nutritional value.

The specific niches where they were growing included the inside core forest (Community as well as National), trail side, along with the fences or farm boundaries while others were mainly growing in streamside and uncultivated areas. However, these plants received minimum or no agronomic attention and most often get waste at the time of peak production.

Some of these plants were observed on market places being sold at competitive prices. Specific household members consume these plants. Some market data was recorded e.g., powder of Rhamnaceae Plant (Sutpi) plant's fruit was sold US $\$ 1.5 / \mathrm{Kg}$ by a house. From Brahmin community selling of NIURO/Circinate fern occasionally is practiced. There was no trend of good agricultural practices; they did that only in season for paddy and millet, not for vegetable and fruit. So, their collection from wild habitat was for themselves only. Further, the people of the study area have followed Gurung culture and per them, selling of growing plants to generate money are against their religion. "Social prestige is often worth more than money in the Gurung societies". So, there is the absence of marketing trend. They collect the plant product for their own utilization or use as gift items to visit their relatives. In a perfectly competitive market, no species would be considered "underutilized:" its use would reflect its low value, and limitation of its collection or cultivation to specific areas would be justified. As argued above, plant species are underutilized because of market imperfections. These days by the commercialization and easy accessibility of market as well as other facilities, the community began to realize the importance of money by selling their product.

The lack of economic information and the lack of product knowledge can negatively contribute to the failure in the market. The lack of knowledge can be a market constraint, resulting in a lower demand than what it would be under full information. Although the study is not carried out sound economic analysis but data clearly shows that the neglected species are an important source of household incomes and can contribute to poverty reduction. Such species can be introduced to the study area by marketing development. The market can be developed by increasing market demand through the promotion of their value with better scientific knowledge. These plants can be conserved and utilized in home stay which is flourishing from the study area.

Lack of attention of NUS by stakeholders in the industry meant that their potential value is under-estimated and under-exploited. It also places them in danger of continued genetic erosion and disappearance which would further restrict development options for the poor. To avoid or at least minimize the impending genetic and cultural erosion concerning traditional and neglected plants, their germplasm should intensively be collected and conserved on-farm as well as in gene banks. The related indigenous understanding urgently needs to be documented for serving future generations. The cultivation methods of these plants should be studied and improved. Their nutritional value needs to be analyzed and recognized. In addition, their utilization should be promoted to improve livelihoods. Encouraging farmers to continue growing these traditional crops is also a challenge. Recognizing the role played by farmers as custodians of local diversity is an influential way to reinforce the self-esteem of community members and thus to contribute towards a self-sustainable and righteous circle for on-farm conservation.

Some strategies aiming at conserving these plant species focus on the promotion of their use and conservation including the strengthening of the market system. The starting point is, therefore, collection and synthesis of knowledge of the obtainable situation within the authorization region through a survey. The survey therefore aimed at i) identifying underutilized fruit species ii) identify the gaps in the product value chain where www.tropicalplantresearch.com 
there was underutilization and iii) identify the major cultivation constraints. To provide policy makers with more detailed, robust and convincing economic data, it is recommended that a scientifically well-designed socio-economic study be conducted on the identified species.

\section{CONCLUSION}

Owing to no prior documentation of the plants from the studied area, this research focused in the enumeration of plants may help in developing a conceptual framework whereby so called useless plants could be employed for the benefit of the mankind. This study revealed that these plants endow several beneficial aspects and could be highly beneficial if these resources could be tapped properly. Also, creating the awareness about the utilization of the beneficial aspects of these plants may help uplift the socio-economic condition of the local inhabitants. In addition, alternative beneficial aspects and the rigorous scientific discourse could also be carried out utilizing these plants.

\section{ACKNOWLEDGEMENT}

I am highly acknowledgment the PEACE Programme of USC Canada/MDO and its employees for their contribution in field study. The gratitude is extending towards my friend Bikash Baral, Ph.D. scholar for his incessant encouragement to carry out this research. I cannot remain quite without giving sincere thanks to the villager of the study area, especially Prem Gurung, Sri Prasad Gurung and Hiralal Gurung.

\section{REFERENCES}

Akhtar F (2001) Uncultivated food in the context of poor people's livelihood. A Nayakrishi experience. In: Johnston MM (ed) Uncultivated foods and Biodiversity. September 24-26, Kathmandu, Nepal, pp. 8-17.

Aryal KP (2010) Uncultivated plants in Nepal: An assessment of their richness and role in the livelihood and culture of two indigenous communities. Lap Lambert Academic Publishing GmbH and Co. KG, Germany.

Bajpai O, Pandey J \& Chaudhary LB (2016) Ethnomedicinal uses of tree species by Tharu tribes in the Himalayan Terai region of India. Research Journal of Medicinal Plant 10(1): 19-41.

Banerji ML (1955) Some edible and medicinal plants from east Nepal. Journal of the Bombay Natural History Society 35: 153-155.

Bussmann RW, Gilbrreath GG, Solio J, Lutura M, Latuluo R, Kunguru K, Wood N \& Mathenge SG (2006) Plant use of the Maasai of Sekenani valley, Maasai Mara, Kenya. Journal of Ethnobiology and Ethnomedicine 2: 22.

Cavender A (2006) Folk medicinal uses of plant foods in Southern Appalchia United states. Journal of Ethnopharmacology 108: 74-84.

CGIAR (2004) Innovation in Agricultural Research Annual Report. Consultative Group on International Agricultural Research (CGIAR), Secretariat, Washington DC, United Nations.

Dobremez JF (1976) Exploitation and prospects of medicinal plants in eastern Nepal In: Mountain Environment and Development Swiss Association for Technical Assistance in Nepal. Kathmandu, Nepal.

Dutta G, Baruah G \& Devi A (2016) Wild food plants of Mishing tribe- An ethnobotanical survey. Tropical Plant Research 3(1): 221-223.

Eyzaguirre PB, Padulosi S \& Hodgkin T (1999) IPGRI's strategy for neglected and underutilized species and the human dimension of agro-biodiversity. In: Padulosi S (ed) Priority-setting for Underutilized and Neglected Plant Species of the Mediterranean Region. International Plant Genetic Resources Institute (IPGRI), Rome.

FAO (1996) Global Plan of Action for the Conservation and Sustainable Utilization of Plant Genetic Resources for Food and Agriculture, Section 12. Food and Agricultural Organization of the United Nations, Rome, Italy.

FAO (2007) Biodiversity for a world without hunger. Food and Agricultural Organization of the United Nations. Available from: http://www.fao.org/biodiversity/components/plants/en/ (accessed: 23 Dec. 2016).

Fuleky G (2009) Cultivated Plants, Primarily as Food Sources Vol 1: Cultivated plants, primarily as food sources. Encyclopedia of Life Support Systems (EOLSS).

Hara H \& Williams LHJ (1979) An enumeration of the flowering plants of Nepal, Vol 2. British Museum (Natural History), London, UK.

Hara H, Chater AO \& Williams LHJ (1982) An enumeration of the flowering plants of Nepal, Vol 3. British Museum (Natural History), London, UK. 
Hara H, Stearn WT \& Williams LHJ (1978) An enumeration of the flowering plants of Nepal, Vol 1. British Museum (Natural History), London, UK.

ICIMOD (2010) Mountain Biodiversity of the Hindukush-Himalayas. International Year of Biodiversity.

Joshi N, Kehlenbeck K \& Brigitte LM (2007) Traditional, neglected vegetables of Nepal: Their sustainable utilization for meeting human needs. In: Conference on International Agriculture Research for Development. University of Kassel- Witzerhousen and University of Gottingen.

Manandhar NP (1982) Wild Edible Plants of Nepal. Bulletin of Department of Medicinal Plant No. 11.

Manandhar NP (2002) Plants and people of Nepal. Timber Press Portland Oregon, USA.

Pandey BD (1964) The wealth of medicinal plants of Nepal. In: Peking Symposium, China, pp. 183.

Pieroni A, Houlihan L, Ansari N, Husain B \& Astam S (2007) Medicinal perception of vegetable traditionally consumed By South- Asian migrants living in Bradford, northern England. Journal of Ethnopharmacology 113:100-110.

Polunin O \& Stainton A (1984) Flowers of the Himalaya. Oxford University Press.

Prescott-Allen OC \& Prescott-Allen R (1990) How many plants feed the world? Conservation Biology 4: 365374.

Scherrer AM, Motti R \& Weckerle CS (2005) Traditional plant use in the areas of Monte Vesole and Ascea, Cilento National Park. Journal of Ethnopharmacology 97(1):129-143.

Shrestha K (1998) Dictionary of Nepalese Plant Names. Mandala Book Point, Kantipath Kathmandu.

Shrestha PM \& Dhillon SS (2006) Diversity and traditional knowledge concerning wild food species in a locally managed forest in Nepal. Agroforestry Systems 66: 55-63.

Stainton A (1988) Flowers of Himalaya: A supplement. Oxford University Press.

WCMC (1994) Groombridge B (ed) Biodiversity Data Source Book. World Conservation Press, Cambridge, United Kingdom. 